\title{
Analysis of Accounting Student Perceptions towards the Desire for a Career as Qualified Accountants: Case Study on Higher Education in Medan
}

\author{
Asriyati \\ Politeknik Negeri Medan \\ Amran Harun \\ Politeknik Negeri Medan
}

\begin{abstract}
The purpose of this research is to identify and analyze what factors influence accounting students to have a career as qualified accountants. The short term goal of this research is that the identification results of this study can be used as a basis for the preparation of learning and non-learning programs and strategies that can increase the interest of accounting students to pursue a career as qualified accountants. While the long-term goal is to increase the interest of accounting students to have a career as a qualified accountant, so that Indonesian accountants can catch up. Data were collected by distributing questionnaires to 374 accounting students in four randomly selected tertiary institutions. The tertiary institution which is the place of research consists of two state universities and two private universities with the largest number of accounting students in the city of Medan. The data collected will be tested using multiple linear regression models, to see salaries, opportunities to progress and students' perceptions about the accountant profession about the desire of students to have a career as a qualified accountant.
\end{abstract}

Keywords: Perception, Accountant, Qualified, Career

DOI: $10.7176 /$ RJFA/11-2-10

Publication date: January $31^{\text {st }} 2020$

\section{Introduction}

Accounting is a system of recording, classifying, and summarizing financial information in such a way that users of information can make economic decisions based on it. An accountant is a professional who performs accounting functions such as auditing or financial statement analysis. Accountants can be employed with accounting firms or large companies with internal accounting departments, or they can regulate individual practices. Accountants are certified by national professional associations after meeting country-specific requirements, although people who do not qualify can still work under other accountants or independently (Kindig, 2019. https://bizfluent.com/about4731157-historical-development- accounting.html)

With the advent of the Industrial Revolution at the end of the 18th century and the beginning of the 19th century, accounting developed even further and stood alone as a profession. Cost accounting practices become prevalent when business owners and managers try to understand the best ways to make their business as efficient as possible. Josiah Wedgwood, owner of the famous British pottery factory, was the first to use cost accounting to understand what his company was spending and to eliminate unnecessary expenses. With the new complexity of accounting and the increasing demand for accurate bookkeeping, people began to specialize in accounting, thus becoming the first professional public accountant. Some accounting companies that are still operating today were founded in the mid-nineteenth century. William Deloitte opened his company in 1845, and Samuel Price and Edwin Waterhouse opened a business with them in 1849 .

Today accountants are a stand-alone profession with thousands of practitioners around the world and a large number of professional organizations and official guidelines for developing practices and regulations. Especially in the United States during the 'great depression', demands were made to better standardize accounting practices and set professional guidelines. At present, Generally Accepted Accounting Principles, or GAAP, set standards that must be used by a public accountant. Each country has a similar set of accounting guidelines.

Because of the complex nature of the current economic system, specialized accounting branches have developed. In addition to traditional financial accounting, there are now subdivisions, such as tax accounting, management accounting, lean accounting, fund accounting and project accounting. Professional accountants are needed for these fields, because they involve the need for a thorough and specific understanding of business needs and accounting practices.

To practice the accounting profession in Indonesia, individuals must become members of the Indonesian Institute of Accountants (IAI) (for accountants) or the Indonesian Institute of Certified Public Accountants (IAPI) (for 
public accountants)). Under Minister of Higher Education Decree No. 153 of 2014 concerning the Professional Accounting Education Program, the successful completion of Professional Accountant Education / Professional Accounting Education Program (PPAk) is a prerequisite for membership in one of the accounting bodies. People who pass the PPAk are issued with a registered State Accountant / State Accreditation (Ak) by the Financial Professional Development Center / Financial Services Professional Supervision Center (PPPK). Both IAI and IAPI set requirements for each membership, including qualification exams, practical experience, and ongoing professional development (IFAC, 2016).

In its development, the accountant profession is still far behind compared to its neighbors in ASEAN. Indonesia is the most populous population in ASEAN, and produces the most accounting graduates in ASEAN each year, an average of around 35,000 graduates. However, for the number of professional accountants based on population ratios, Indonesia ranks only 6th, far below Singapore, Malaysia, Thailand and Phiphina and slightly below Brunei.

Tables 1 and 2 show data on the number of accounting graduates per year, the number of professional accountants, and the number of accountants per one million population in ten ASEAN countries.

Table 1. Number of Accounting Graduates per Year and Number of Accountants Join the Professional Accountants Association in the Ten ASEAN Countries

\begin{tabular}{|l|l|l|l|}
\hline No & Country & $\begin{array}{l}\text { Number of Accounting Graduates } \\
\text { Every Year }\end{array}$ & $\begin{array}{l}\text { Number of Accountants in the Professional } \\
\text { Accountants Association (2015) }\end{array}$ \\
\hline 1 & Brunei & 250 & 56 \\
\hline 2 & Cambodia & - & 291 \\
\hline 3 & Indonesia & 35.000 & 24.587 \\
\hline 4 & Lao PDR & 1.080 & 176 \\
\hline 5 & Malaysia & 5.000 & 31.815 \\
\hline 6 & Myanmar & - & 1.948 \\
\hline 7 & Philiphines & 15.000 & 18.214 \\
\hline 8 & Singapore & 1.000 & 28.891 \\
\hline 9 & Thailand & 20.000 & 62.739 \\
\hline 10 & Vietnam & 2.000 & 9.800 \\
\hline & AMOUNT & & $\mathbf{1 7 8 . 5 1 7}$ \\
\hline
\end{tabular}

Source: Avianti (2015)

Table 2. Number of Population in Thousands and Number of Accountants by One Million Population in Ten ASEAN Countries

\begin{tabular}{|l|l|l|l|}
\hline No & Country & $\begin{array}{l}\text { Number of Population in } \\
\text { Thousands (Dec'2014) }\end{array}$ & $\begin{array}{l}\text { Number of Accountants Every One Million } \\
\text { Population }\end{array}$ \\
\hline 1 & Brunei & 406,2 & 138 \\
\hline 2 & Cambodia & $14.962,6$ & 19 \\
\hline 3 & Indonesia & $248.818,1$ & 99 \\
\hline 4 & Lao PDR & 6.644 & 26 \\
\hline 5 & Malaysia & 29.948 & 1.062 \\
\hline 6 & Myanmar & 61.568 & 32 \\
\hline 7 & Philiphines & $99.384,5$ & 183 \\
\hline 8 & Singapore & $5.399,2$ & 5.351 \\
\hline 9 & Thailand & 68.251 & 919 \\
\hline 10 & Vietnam & $89.708,9$ & 109 \\
\hline & AMOUNT & & \\
\hline
\end{tabular}

Source: Avianti (2015) 
From the table above it is clear that Indonesia is still far behind in the provision of professional accountants compared to neighboring countries. Whereas on the one hand the Department of Accounting is one of the most favored majors and in fact the development and growth of business and government in Indonesia still very much requires professional accountants (Avianti, 2015).

Many studies have been conducted with the aim of identifying what factors motivate or influence the desires of a (graduate) accounting graduate to pursue a career as a qualified professional accountant or not. Among these are research conducted by Abdullah and Zakaria (2006), Mustapha and Abu Hasan (2012), and Abdul Aziz, et al (2017). All three studies were conducted in Malaysia.

Mustapha and Abu Hasan (2012) sought to explore perceptions of accounting students on professional examinations and the factors influencing their decision to take the exam. The results show that about $70 \%$ of respondents plan to work immediately after graduation, and only about $28 \%$ of respondents actually have the intention to pursue professional qualifications. Research reveals that job security and stability, and opportunities for progress and students' perceptions of the profession are the three main variables found to be significant in influencing the decision of accounting students to pursue professional examinations.

Abdul Aziz et al (2017) conducted a study whose results showed that when studying independent variables individually, only three independent variables had a significant relationship with students' intentions to pursue professional qualifications. This is job security or stability, financial assistance and grit. This finding has implications for accounting educators as well as other professional bodies and related organizations in their efforts to increase the number of professionally qualified accountants in Malaysia. Whereas Abdullah and Zakaria (2006) found that students rated opportunities and progress as the most important attributes followed by office atmosphere / staff friendliness and company training programs. The findings from this study can help public accounting firms in developingpolicies that might attract more quality recruitment. They can also be used by higher education institutions to provide more appropriate career advice to students who are looking for their first accounting job.

Based on the phenomenons and previous research above, the authors are interested in conducting research on what factors influence the desires (candidates) of accounting graduates in Medan to pursue a career as a qualified professional accountant. This study will examine the factors of salary (salary), opportunities for advancement and student perceptions of the accounting profession.

\section{Literature Review}

\subsection{Theory Description}

\subsubsection{Qualified Professional Accountants}

An accountant is someone who has the skills and experience needed to build and maintain accurate financial records for individuals or businesses. The duties of an accountant can include designing and controlling the records system, audit books, and preparing financial reports. An accountant can provide tax advice and prepare a tax report (West's Encyclopedia of American Law edition 2, 2008 . https://legaldictionary.thefreedictionary.com/Qualified+Accountant.)

Because accounting is a practical profession, having the right mix of qualifications and experience makes a sizeable part of the accounting syllabus/curriculum. The quality of accountants and critical quality for business success is obtained through the practical segment of the entire training that accountants go through. Some professional accounting bodies such as ACCA have accredited training / recruitment partners who place student accountants in the right position to enable them to obtain what is needed in job training. This training usually cuts four main aspects of accounting-financial accounting, managerial accounting, auditing and taxation. Consultation experience was also gained by accountant training participants (Hybrid Accountant, 2012) https://accountantnextdoor.com/qualified-accountant-who-is-aqualifiedaccountan $t /$ ).

To practice the accounting profession in Indonesia, individuals must become members of the Indonesian Institute of Accountants (IAI) (for accountants) or the Indonesian Institute of Certified Public Accountants (IAPI) (for public accountants)). Under Minister of Higher Education Decree No. 153 of 2014 concerning the Professional Accounting Education Program, the successful completion of Professional Accountant Education / Professional Accounting Education Program (PPAk) is a prerequisite for membership in one of the accounting bodies. People who pass the PPAk are issued with a registered State Accountant / State Accreditation (Ak) by the Financial Professional Development Center / Financial Services Professional Supervision Center (PPPK). Both IAI and IAPI set requirements for their respective membership respectively, including qualification exams, practical experience, and ongoing professional development (IFAC, 2016). 


\subsubsection{Factors Influencing the Decision to Become a Qualified Professional Accountant}

\subsubsection{Salary}

McLean et al (1996) and Said et al (2004) state that starting salary is an important criterion for choosing accounting as a career, in addition to being a 'hygiene factor' that motivates an individual. Abdullah and Zakaria (2006) conducted research at two state universities in Malaysia and found the expected salary in the future was an important attribute for students who wanted to join a public accounting firm. A study conducted by Ghani et al (2008) shows that first-year accounting students view salary as a major factor in making an accountant happy.

Horowitz and Riley (1990) who claim that one of the top criteria that influence students' career decisions is the salary offered to them. Another study by Trump and Hendrickson (1970) found that starting salary was one of the main job characteristic preferences by undergraduate accounting majors. However, this result is not supported in studies by Mustapha and Abu Hassan (2012) and Law (2010) who did not find salary to be a significant factor in motivating students to pursue CPA careers. Likewise, Abdul Aziz et al (2017) found no significant effect of salary on the desire to become a qualified professional accountant.

\subsubsection{Opportunities for Forward}

Another variable that is claimed to influence students' career choice decisions as professional accountants is the opportunity to advance in the profession. Carpenter and Strawser (1970) found that opportunities for progress were better in the accounting field compared to other fields. This opportunity gives them a challenge to prove they can do the job. Abdullah and Zakaria (2006) found evidence that opportunities to advance as the most important attribute for accounting students to join with public accounting firm especially among male students. This finding was reinforced by Mustapha and Abu Hassan (2012) who also found that opportunities for advancement were positively correlated with students' career choices as professional accountants, while Abdul Aziz et al (2017) did not find a significant influence on opportunities to progress towards the desire to become professional accountants qualified.

A study conducted by Said et al. (2004) found that this factor ranks high in influencing career choices in accounting among Malaysian students. Another study by Ahmadi et al. (1995) found that career advancement was also a major factor for female accounting students in their job selection decisions. This is supported by other research by Trump and Hendrickson (1970) who found that this factor is one of the most important considerations in career decisions of accounting students and is listed as the first or second most important criterion in their career choice criteria .

\subsubsection{Students' Perceptions of the Accountant Profession}

One factor that is usually considered by accounting students in their decisions is their perception of the profession (Omar, 2009). Some accounting students think that it is difficult and difficult to pass a professional accounting program and only a few finalists graduate with just one effort. Malthus and Fowler (2009) come to conclusions that are consistent with research conducted in New Zealand which has concluded that tertiary students and secondary school teachers consider accounting to be boring. Students see accounting as a boring subject and accountants who are closed and not too pleasant to be around, when they sit at a desk all day and count numbers, they have poor social skills and don't do much outside, not outsiders and they don't have a sense of humor (Malthus et al, 2009). Mustapha and Abu Hasan (2012) found a significant influence on students' perceptions of the accountant profession on the variable desire to become a qualified professional accounting.

\subsection{Thinking Framework and Hypothesis Development}

\subsubsection{Salary and the desire for a career as a qualified accountant}

Many studies have succeeded in proving that the salary factor is one of the most important factors for a graduate to decide on a career in accounting (McLean et al, 1996; Said et al, 2004; Abdullah and Zakaria, 2006; Ghani et al, 2008; Horowitz and Riley, 1990; Trump and Hendrickson, 1970). The salary factor is a factor that motivates an accountant, and is considered as something that makes an accountant happy. The initial salary is also considered as the starting point that determines the amount of the next step.

Based on the framework of thought and previous studies, the research hypothesis was formulated:

H1: There is an effect of salary on students' desire to have a career as a qualified accountant. 


\subsubsection{Opportunities to progress and the desire to have a career as a qualified accountant}

Research conducted by Carpenter and Strawser (1970), Abdullah and Zakaria (2006), Mustapha and Abu Hassan (2012), Said et al. (2004), Ahmadi et al. (1995) managed to prove that the opportunity to advance is a factor that influences the desire to have a career as an accountant. The opportunity to advance is a challenge to prove that they can do their work.

Based on the framework of thought and previous studies, the research hypothesis was formulated:

$\mathrm{H} 2$ : There is an influence of the opportunity to advance on the desire of students to pursue a career as a qualified accountant

\subsubsection{Students' perception of the accountant profession to progress and the desire to have a career as a}

qualified accountant

Omar (2009), Malthus and Fowler (2009), Malthus et al, (2009) and Mustapha and Abu Hasan (2012) found that students' perceptions of the accounting profession affected the desire to have a career as a professional accountant. An accountant's job tends to be considered as a boring job, as well as an accountant is considered as someone who has no sense of humor. There is also a perception that obtaining recognition of qualifications is very, very difficult.

Based on the framework of thought and previous studies, the research hypothesis was formulated:

H3: There is an influence of perception on the accountant profession on the desire of students to have a career as a qualified accountant.

\section{Purpose and Benefits of Research}

\subsection{Research Purposes}

Based on the problem formulation, the objective of the research is to test:

1. Does the salary factor influence the desire of accounting students to have a career as a qualified accountant.

2. Does the opportunity to progress affect the desire of accounting students to have a career as a qualified accountant.

3. Does the student's perception of the accounting profession affect the desire of accounting students to have a career as a qualified accountant.

\subsection{Benefits of Research}

The expected benefits of this research are:

1. Targeted findings: the results of this study are expected to identify what factors influence accounting students to pursue a career as qualified accountants. From the results of this identification can be used as the basis for the preparation of programs and learning strategies and non-learning that can increase the interest of accounting students to have a career as a qualified accountant

2. Fundamental contribution to a field of science: contributions that can be given through the results of this study are contributions to the field of accounting as a whole, because with appropriate learning or nonlearning strategies, will increase student interest in mastering skills in accounting for the future able become a qualified accountant.

\section{Methodology Research}

The model of this research is quantitative descriptive research. Descriptive research is research that explains the phenomena that occur at this time. The phenomenon that wants to be investigated is about the desire of students to have a career as a qualified accountant. It is suspected that there are various factors that influence, including salary, opportunities to advance, and student perceptions of the accounting profession. The research model can be described as follows:

$$
\mathrm{Y}=\mathrm{a}+\mathrm{b} 1 \mathrm{X} 1+\mathrm{b} 2 \mathrm{X} 2+\mathrm{b} 3 \mathrm{X} 3+\mathrm{e}
$$




$$
\begin{aligned}
& \mathrm{Y}=\text { desire of students to pursue a career as a qualified accountant } \\
& \mathrm{X} 1=\text { salary } \\
& \mathrm{X} 2 \text { = opportunity to advance } \\
& \mathrm{X} 3=\text { student perception }
\end{aligned}
$$

The parameters used in this study are salary indicators, opportunities for advancement, perceptions of the accountant profession and a desire to have a career as a qualified accountant using a research instrument in the form of a questionnaire adapted from research conducted by Mustapha and Abu Hasan (2012) and Aziz et al (2017). Indicators will be measured using a linkert scale.

Data was collected by distributing questionnaires to accounting students in the city of Medan. In this case two private tertiary institutions and two state tertiary institutions will be chosen, to represent public and private campuses. The questionnaire will be distributed to 374 accounting students in four selected tertiary institutions, namely USU, Polmed, UNPAB and UMI. These four colleges were chosen because they are the state and private universities with the largest number of accounting students in Medan. Criteria for students who are sampled are students who must be accounting students of S-1, D-3 or D-4 Study Programs who have received auditing courses. This criterion is established with the thought that students who have received auditing courses have been get enough picture about the accountant profession. A sample size of 374 was determined using the Slovin formula, with an error rate of $5 \%$. The research subjects were tertiary institutions in the city of Medan, both public and private.

\section{Results and Discussion}

\subsection{Research Results}

\subsubsection{Test Validity}

Validity test is done on the basis of decision making Product Moment Validity Test, namely by comparing the value of sig. (2-tailed) with a probability of 0.05 :

1. If the value of sig. (2-tailed) $<0.05$ and Pearson correlation is positive. Then, the questionnaire items are valid.

2. If the value of sig. (2-tailed) $<0.05$ and Pearson correlation is negative. Then, the item about the questionnaire was invalid.

3. If the value of sig. (2-tailed) $>0.05$ then the item about the questionnaire is invalid.

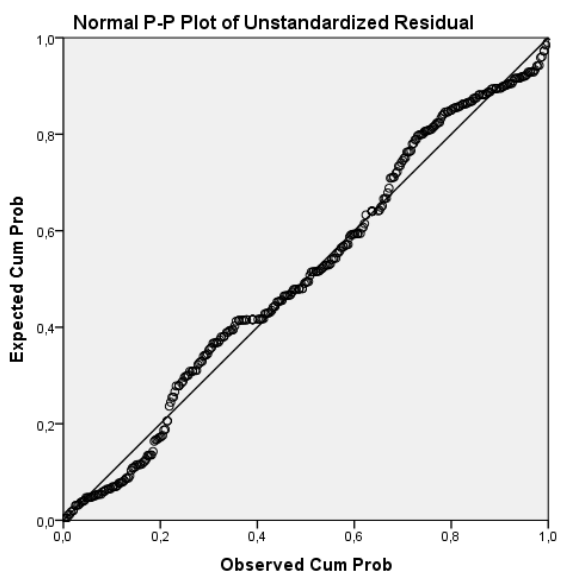


Table 3. Validity Test Results

\begin{tabular}{|c|c|c|c|c|c|}
\hline & $\begin{array}{c}\text { Item } \\
\text { Questions }\end{array}$ & $\begin{array}{c}\text { Correlation } \\
\text { Coefficient }\end{array}$ & $\begin{array}{c}\mathbf{r}_{\text {tabel }} \\
(n=369)\end{array}$ & Sig $(<5 \%)$ & Information \\
\hline $\begin{array}{l}\text { The desire of } \\
\text { students to } \\
\text { pursue a career } \\
\text { as a qualified } \\
\text { accountant }\end{array}$ & Y1 & 1,000 & 0.095 & 0,000 & Legitimate \\
\hline \multirow{7}{*}{$\begin{array}{l}\text { Opportunities } \\
\text { for Forward }\end{array}$} & X1_1 & 0,506 & 0.095 & 0,000 & Legitimate \\
\hline & $\mathrm{X} 1 \_2$ & 0,465 & 0.095 & 0,000 & Legitimate \\
\hline & $\mathrm{X} 1 \_3$ & 0,587 & 0.095 & 0,000 & Legitimate \\
\hline & $\mathrm{X} 14$ & 0,730 & 0.095 & 0,000 & Legitimate \\
\hline & X1_5 & 0,503 & 0.095 & 0,000 & Legitimate \\
\hline & X1_6 & 0,446 & 0.095 & 0,000 & Legitimate \\
\hline & $\mathrm{X} 17$ & 0,507 & 0.095 & 0,000 & Legitimate \\
\hline \multirow{6}{*}{ Salary } & $\mathrm{X} 2 \_1$ & 0,415 & 0.095 & 0,010 & Legitimate \\
\hline & $\mathrm{X} 22$ & 0,624 & 0.095 & 0,000 & Legitimate \\
\hline & $\mathrm{X} 23$ & 0,704 & 0.095 & 0,000 & Legitimate \\
\hline & $\mathrm{X} 2 \_4$ & 0,436 & 0.095 & 0,000 & Legitimate \\
\hline & $\mathrm{X} 25$ & 0,532 & 0.095 & 0,000 & Legitimate \\
\hline & $\mathrm{X} 26$ & 0,498 & 0.095 & 0,000 & Legitimate \\
\hline \multirow{3}{*}{$\begin{array}{l}\text { Perception of } \\
\text { Student }\end{array}$} & X3_1 & 0,721 & 0.095 & 0,000 & Legitimate \\
\hline & $\mathrm{X} 32$ & 0,855 & 0.095 & 0,000 & Legitimate \\
\hline & $\mathrm{X} 3 \_3$ & 0,719 & 0.095 & 0,000 & Legitimate \\
\hline
\end{tabular}

Data Normality Test

\subsubsection{Classical Assumption Test}

From the distribution of data seen on the P plot above, it can be concluded that the data are normally distributed.

\section{Multicollinearity Test}

\begin{tabular}{|c|c|c|c|}
\hline \multicolumn{4}{|c|}{ Coefficients $^{a}$} \\
\hline \multirow{2}{*}{\multicolumn{2}{|c|}{ Model }} & \multicolumn{2}{|c|}{ Collinearity Statistics } \\
\hline & & Tolerance & VIF \\
\hline & Opportunities For Forward & ,786 & 1,272 \\
\hline 1 & Salary & ,776 & 1,289 \\
\hline & Students Perception & ,805 & 1,242 \\
\hline
\end{tabular}

a. Dependent Variable: Student desires

From the statistical test table, it can be seen that for all independent variables, the VIF value $<10$. This shows that there is no multicollinearity problem in the multiple regression equation tested. 


\subsubsection{Statistical Test Results}

\section{Model Summary}

\begin{tabular}{|l|r|r|r|r|}
\hline Model & $\mathrm{R}$ & \multicolumn{1}{|c|}{ R Square } & Adjusted R Square & Std. Error of the Estimate \\
\hline 1 &, $365^{\mathrm{a}}$ &, 133 &, 126 &, 702 \\
\hline
\end{tabular}
a. Predictors: (Constant), Students Perception, Opportunities for Forward, Salary
b. Dependent Variable: Student Desire

\begin{tabular}{|rl|r|r|r|r|r|}
\hline \multicolumn{1}{|c|}{ ANOVA $^{\mathrm{a}}$} \\
\hline \multirow{2}{*}{1} & Sum of Squares & \multicolumn{1}{c|}{ df } & Mean Square & \multicolumn{1}{c|}{$\mathrm{F}$} & \multicolumn{1}{c|}{ Sig. } \\
\hline & Regression & 26,609 & 3 & 8,870 & 17,976 &, $000^{\mathrm{b}}$ \\
& Residual & 173,183 & 351 &, 493 & & \\
& Total & 199,792 & 354 & & & \\
\hline
\end{tabular}

a. Dependent Variable: Student Desire

b. Predictors: (Constant), Students Perception, Opportunities for Forward, Salary

\begin{tabular}{|c|c|c|c|c|c|c|}
\hline \multirow{2}{*}{\multicolumn{2}{|c|}{ Model }} & \multicolumn{2}{|c|}{$\begin{array}{c}\text { Unstandardized } \\
\text { Coefficients }\end{array}$} & \multirow{2}{*}{$\begin{array}{c}\begin{array}{c}\text { Standardized } \\
\text { Coefficients }\end{array} \\
\text { Beta }\end{array}$} & \multirow[t]{2}{*}{$\mathrm{T}$} & \multirow[t]{2}{*}{ Sig. } \\
\hline & & $\mathrm{B}$ & Std. Error & & & \\
\hline \multirow{4}{*}{1} & (Constant) & 1,407 & ,403 & & 3,488 & 001 \\
\hline & Peluang_untuk_maju & 088 & ,014 & ,341 & 6,082 & 000 \\
\hline & Salary &,- 001 & ,014 &,- 003 &,- 056 & ,955 \\
\hline & Persepsi_mahasiswa & ,024 & ,023 & 059 & 1,063 & ,288 \\
\hline
\end{tabular}

\subsection{Discussion}

\subsubsection{Value of Adjusted R - Square}

From the table of statistical test results, it appears that the value of Adjusted R-Square is 0.126. The number shows the meaning that the three independent variables explain $12.6 \%$ the dependent variable, while the remaining $86.5 \%$ is explained by other factors.

\subsubsection{Anova Test Results}

From the ANOVA test results, it appears that the significance value is 0,000 , and this value $<0.05$. This value implies that the multiple linear regression model used meets the fit of the model, or in other words it can be used to test hypotheses at the level of significance 0.05 . 


\subsubsection{Hypothesis Test Results}

Hypothesis test results show the following results:

1. The significance value of the variable "Opportunity for Forward" is equal to 0,000 . This value $<0.05$, which implies that the independent variable "Opportunity for Forward" affects the dependent variable "Desire to Become a Qualified Accountant" at the level of significance 0.05. This result implies that H1 was accepted.

2. The significance value of the "Salary" variable is 0.955 . This value $>0.05$, which implies that the independent variable "Salary" does not affect the dependent variable "Desire to Become a Qualified Accountant" at the level of significance 0.05. This result implies that $\mathrm{H} 2$ was rejected.

3. The significance value of the variable "Student Perception" is 0.288 This value $>0.05$, which implies that the independent variable "Student Perception" does not affect the dependent variable "Desire to Become a Qualified Accountant" at the level of significance 0.05. This result implies that $\mathrm{H} 3$ is rejected.

\section{Conclusion and Suggestion}

\subsection{Conclusion}

From the results of statistical tests, it can be concluded that only one variable, namely the opportunity to progress variable, influences the desire to have a career as a qualified accountant, while the other two variables, namely salary and student perceptions of accountants, are found to have no effect.

These results imply that there are many other factors that are expected to influence the desire of students to pursue a career as a qualified accountant. Adjusted R-Square value of 0.126 also reinforces this, because the value implies that the independent variables tested are only able to explain $12.6 \%$ of the dependent variable.

\subsection{Suggestion}

From the conclusions above, it is recommended that further research be able to test other variables that are thought to influence the desire of students to pursue a career as a qualified accountant. Based on the results of these studies, it is expected that regulators and academics can create an environment and atmosphere that can increase the interest of accounting students to become qualified accountants.

\section{References}

Abdullah, M., \& Zakaria, Z. 2006. Desired attributes of public accounting firms from accounting students' perceptions: the case of University of Malaya \& International Islamic University of Malaysia. Journal of Financial Reporting and Accounting, vol.4 no. 2537.

Ahmadi, M., Helms, M.M., \& Nodoushani, P. 1995. A factor analytic approach profiling job selection differences of male and female accountants. Managerial Auditing Journal, vol. 10 no. 7 pp. 17-24.

Aziz, D. A., Mohd A.I, Morni, H.J.S., \& Mazilena, T. 2017. Accounting Students' Perception And Their Intention To Become Professionally Qualified Accountants. SHS Web of Conference.

Carpenter, C. G., \& Strawser, R. H. 1970. Job Selection Preferences of Accounting Student. Journal of Accountancy, vol.29 no.6 pp. 84-86.

Ghani, E. K., Said, J., Mohd Nasir, N., \& Jusoff, K. 2008. The 21 st century accounting career from the perspective of the Malaysian university students. Asian Social Science, vol. 4 no. 7383.

Horowitz, K., \& Riley, T. 1990. How do accounting students see us. Accountancy pp. 75-79.

Hybrid Accountant. 2012. Qualified Accountant: Who Is A Qualified Accountant? https://accountantnextdoor.com/qualified-accountant-who-is-a-qualifiedaccountan t/. Diakses tanggal 14 Agustus 2019 pukul 15.12.

International Federation of Accountant. 2016. https://www.ifac.org/about-ifac /membership/country/indonesia. Diakses tanggal 14 Agustus 2019 pukul 15.12 
Kindig, Alexis. 2019. Historical Development of Accounting. https:// bizfluent.com/about-4731157-historicaldevelopment-accounting.html/. Diakses tanggal 14 Agustus 2019 pukul 15.12.

Malthus, S., \& Fowler, C. 2009. Perception of Accounting: a quantitative New Zealand study. Pacific Accounting Review vol. 21 no.1 pp. 26-47.

Mustapha, M. \& Abu Hassan, M. H. 2012. Accounting students' perception on pursuing professional eaxamination. International Journal of Education vol. 4, pp.1-15.

Omar, N. 2009 . Factors influencing the diploma in accounting (DIA) students'decision to pursue professional accounting programmmes. Thesis Submitted to the College of Business, Universiti Utara Malaysia

Prof. Dr. Ilya Avianti, SE., M.Si., Ak., CPA., CA. 2015. Peluang dan Tantangan Akuntan di Era MEA. Simposium Nasional Akuntansi (SNA) XVIII Medan. http://www.iaiglobal.or.id/. Diakses tanggal 14 Agustus 2019 pukul 15.12.

Qualified Accountant. (n.d.) West's Encyclopedia of American Law, edition 2. (2008). https://legaldictionary.thefreedictionary.com/Qualified+Accountant. Retrieved 14 August 2019 at 15.12.

Said, J., Ghani, E.K., Hashim, A., \& Mohd Nasir, N. 2004. Perceptions towards accounting career among Malaysian undergraduates. Journal of Financial Reporting and Accounting vol.2 pp. 17-30.

Trump, G.W. \& Hendrickson, H.S. 1970. Job selection preferences of accounting students. The Journal of Accountancy pp. 84-86. 